\title{
ANALISIS MULTIPLE INTELLIGENCES DALAM DIRI ANAK MENURUT MUNIF CHATIB
}

\author{
Lailatul Qadariyah \\ Dosen Tetap STIS Nurud Dhalam Ganding-Sumenep \\ Email: Lailatulqadariyah89@gmail.com
}

\begin{abstract}
Konsep pembelajaran berbasis Multiple Intelligences perspektif Munif Chatib adalah suatu koreksi terhadap kecerdasan seseorang tidak hanya berdasarkan pada Intelligences Quotient (IQ) yang hanya mengukur kemampuan seseorang hanya berdasarkan pada linguistik, matematik logis dan spasial saja. Dalam konsep pendidikan Multiple Intellegences Munif Chatib lebih menekankan pada The Best Proses bukan The Best Input dimana sekolah unggul adalah sekolah yang fokus pada kualitas proses pembelajaran, bukan pada kualitas input siswanya. Kedua, menjadi anak terdidik atau istimewa adalah menetekankan pada kreativitas guru dan keahlian dalam mengaplikasikannya, hal ini dapat kita lakukan dalam dunia pembelajaran antara guru dan murid. Munif Chatib mengartikan strategi mengajar dengan menekankan kepada kekreativitas guru sehingga jumlah dan nama strategi itu harus luas dan tak terbatas. Jadi, apapun namanya, strtegi Multiple Intelligences akan menjadi wadah yang sangat luas dan dapat menampung semua istilah metodologi pembelajaran. Guru memberikan wadah bagi siswa untuk Praktek Turun Lapangan (PTL) supaya siswa bisa merasakan betapa indahnya pendidikan. Dan ini merupakan suatu keterampilan guru untuk meningkatkan proses pembelajaran.
\end{abstract}

Keywords: Multiple Intelegences, Anak, Munif Chatib

\section{Pendahuluan}

Sebagai fase golden age, masa kanak-kanak menjadi pembentukan pribadi yang paling tepat untuk mengantarkannya pada masa depan yang cemerlang dan 


\section{Lailatul Qadariyah}

hal tersebut hanya bisa dicapai dengan sistem dan metode pendidikan yang baik dan benar, namun seringkali pada fase inilah kebanyakan anak menjadi pribadi yang tidak terarah diakibatkan oleh metode pendidikan yang tidak tepat.

Transformasi ilmu pengetahuan seringkali menjadi suatu hal yang membosankan, maka dibutuhkan metode khusus agar proses transformasi tersebut berjalan dengan baik dan menyenangkan, menggembirakan, tidak membosankan, tidak menekan, tidak memaksa serta tidak menegangkan. ${ }^{1}$ Faktanya sampai saat ini di Indonesia kesalahan metode dalam mengajar masih banyak terjadi dan yang menjadi korban adalah anak didik kita. Banyak kejadian tentang para guru dan sekolah yang tidak benar-benar adil dalam menilai kecerdasan anak didik. Sekolah, bahkan semua lapisan masyarakat telah membuat definisi yang tidak manusiawi tentang kemampuan. ${ }^{2} \mathrm{Hal}$ itu terjadi, karena indikasi kecerdasan yang selama ini tertanam dalam benak mayoritas orang adalah jika seseorang dapat mengerjakan soal matematika tanpa ada kesalahan maka itulah anak yang pintar dan sering kali cenderung mengklaim mereka yang daya hitungnya lamban dengan predikat bodoh. Padahal dengan dua belahan otak yang dianugerahkan Allah kepada setiap manusia yaitu otak kanan dan otak kiri, dimana keduanya mempunyai fungsi yang melahirkan berbagai macam kemampuan manusia yang berbeda-beda tergantung bagaimana kita dapat memaksimalkan daya tersebut sesuai dengan apa yang dimiliki, karena setiap manusia adalah unik dan setiap manusia mempunyai kelebihan masing-masing. Tidak ada anak yang bodoh semuanya pintar dengan potensinya masing-masing.

Oleh karena itu, upaya perbaikan kinerja pendidik (guru) dalam melakukan proses pendidikan yang menekankan pada perbaikan aktivitas pembelajaran yang terfokus pada pengembangan kecerdasan jamak sangat dibutuhkan dalam rangka untuk mengembangkan kesadaran baru dalam membangun hakekat kebhinekaan dengan menintegrasikan nilai-nilai pluralitas dalam penyelenggaraan pendidikan. Perbaikan kinerja guru memiliki relevansi yang sangat signitifikan dibidang pendidikan karena berpengaruh langsung pada peran guru dan pedagoginya untuk peningkatan peserta didik agar belajar secara efektif. $^{3}$

\footnotetext{
${ }^{1}$ Nano Sunartyo, Membentuk Kecerdasan Anak Sejak Dini (Jogyakarta: Think, 2006), . 97-101.

${ }^{2}$ Munif Chatib, Sekolah Anak-Anak Juara, Berbasis Kecerdasan Jamak Dan PendidikanBerkeadilan (Bandung: Kaifa Learning, 2012), 11

${ }^{3}$ Muhammad yaumi, Pembelajaran Berbasis Multiple Intellegences (Jakarta: Dian rakyat, 2012),7
} 
Baru-baru ini muncul seorang tokoh baru dalam dunia pendidikan Indonesia yaitu Munif Chatib yang mengusung Multiple Intelligencessebagai metode untuk memperbaiki krisis dalam dunia pendidikan dan menebus kembali nilai dan ruh pendidikan yang selama ini tergadai pada arus globalisasi serta menciptakan pendidikan Indonesia yang lebih humanis (berperikemanusiaan). Metode ini sebenarnya sudah lama muncul, namun di Indonesia sendiri baru ramai diperbincangkan pada tahun 2009. Multiple Intelligences atau dapat diartikan sebagai kecerdasan majemuk bukanlah sebuah bidang study dan bukan pula kurikulum akan tetapi merupakan aktivitas pembelajaran dengan model dan kreativitas yang beragam dalam proses belajar mengajar dimana guru sebisa mungkin harus mengenal anak didiknya sedekat mungkin, dari situlah sang guru akan tahu potensi dan tipikal kecerdasan yang dimiliki oleh sang anak untuk digali dan dikembangkan. ${ }^{4}$

Dalam konsep ini lebih menekankan pada The Best Proses bukan The Best Input dimana menurut Munif Chatib sekolah unggul adalah sekolah yang fokus pada kualitas proses pembelajaran, bukan pada kualitas input siswanya. Menurut beliau kriteria sekolah unggul adalah sekolah yang memandang tidak ada siswa yang bodoh dan semua siswanya merasakan tidak ada satupun pelajaran yang sulit dan para gurunya mampu menjamin semua siswa akan dibimbing kearah perubahan yang lebih baik. ${ }^{5}$ Karena ketika setiap kelebihan individu dikembangkan secara maksimal tanpa harus memaksa mereka untuk mempelajari sesuatu yang bukan keahlian mereka maka akan tercipta manusia-manusia unggul dalam berbagai bidang.

Melihat permasalahan pendidikan di tanah air, metode Multiple Intelligences patut untuk dicoba dan diterapakan, sehingga di masa yang akan datang di negeri ini akan tercipta manusia-manusia unggul serta tidak ada lagi predikat bodoh, ${ }^{6}$ karena ternyata semua manusia pintar, istimewa dengan potensi berbeda-beda yang harus dikembangkan. Oleh karena itu penulis sangat tertarik untuk mengetahui lebih lanjut tentang Multiple Intelligences dan penerapannya di Indonesia yang digagas oleh Munif Chatib tersebut.

\footnotetext{
${ }^{4}$ Munif Chatib, Sekolahnya Manusia, Sekolah Berbasis Multiple Intelligences Di Indonesia (Bandung: Kaifa Learning, 2011), xxiii

${ }^{5}$ Ibid, 93.

${ }^{6}$ Munif Chatib, Gurunya Manusia, Menjadikan Semua Anak Istimewa Dan Semua Anak Juara (Bandung: Kaifa learning, 2011), 33.
}

Kariman, Volume 06, Nomor 02, Juni 2018|269 
Lailatul Qadariyah

\section{Pembahasan}

Munif Chatib adalah salah satu aset paling berharga dalam dunia pendidikan kita saat ini.Tak hanya gagasan-gagasannya tentang oembaruan pendidikan di Indonesiasangat mendasar, passion, semangat, dan kerja kerasnya sangat luar biasa.

Dia begitu rajin menjajaka gagasan pembaruannya keseluruh pelosok Indonesia, sering kali dengan menyisikan kepentingan pribadinyasendiri. Menyusul kesuksesan buku sekolah manusia dan buku Gurunya Manusia ini membawa gagasan sang penulis ke level yang lebih tinggi lagi dalam upaya memperbaiki secara terus menerus falsafah, konsep, sistem dan praktek pendidikan di Negri ini. Pemikiran munif menukik sedalam-dalamnya hingga kepraktek pendidikan sehari-hari yang konkret. ${ }^{7}$

\section{Pengertian Multiple Intellegences}

Multiple Intellegences berasal dari bahasa inggris yang mempunyai arti kecerdasan majemuk. Dalam hal ini yang dimaksud Multiple Intelligences adalah metode dalam proses belajar mengajar dimana guru harus memahami dan mampu mengetahui berbagai macam tipe kecerdasan murid yang beragam serta mengembangkannya.

Sebenarnya, Multiple Intellegences adalah sebuah teorikecerdasan yang dimunculkan oleh Dr. Howard Gardner, seorang psikolog dari Project Zero Harvard Univercity pada 1983.sebelum muncul teori Multiple Intellegences teori kecerdasan lebih cendrung diartikan secara sempit. Kecerdasan seseorang lebih banyak ditentukan oleh kemampuannya menyelesaikan serangkaian tes psikologi; kemudian hasil tes itu dirubah menjadi angka standar kecerdasan. ${ }^{8}$

Para ilmuan memahami Intellgences secara berbeda-beda karena kecerdasa sangat sulit untuk didefinisikan.Dalam pengertian yang populer kecerdasan sering didefinisikan sebagai kemampuan mental umum untuk belajar dan menerapkan pengetahuan dalam memanipulasi lingkungan, serta kemampuan untuk berfikir abstrak . ${ }^{9}$

\footnotetext{
7 Munif Chatib, Gurunya Manusia menjadikan Semua Anak Istimewa dan Semua Anak Juara. (Bandung: Mizan Media Utama, 2011). 45

${ }^{8}$ Munif Chatib, Gurunya Manusia menjadikan Semua Anak Istimewa dan Semua Anak Juara. (Bandung: Mizan Media Utama, 2011), 132

${ }^{9}$ Yaumi Muhammad, M. Hum. Pembelajaran berbasi Multiple Intellegences.(JakartaDian rakyat, 2012 ), 109.
} 
Multiple Intellegences bisa disebut dengan kecerdasan jamak yaitu sebagai keterampilan dan bakat yang dimiliki siswa untuk menyelesaikan berbagai persoalan dan pembelajaran. ${ }^{10}$

Sedangkan menurut gardner adalah sebuah kebudayaan yang tercipta dari proses pembelajaran, prilaku, pola kehidupan antar manusia dan alam atau lingkungannya yang terkristalisasi dalam habit (kebiasaan). Dengan demikian kecerdasan adalah sebuah prilaku diulang-ulang. ${ }^{11}$

MI adalah kecenderungan kecerdasan siswa dan gaya belajar siswa. Guru juga harus menyesuaikan gaya mengajarnya dengan gaya belajar siswa. Guru dapat mengajar dengan cara memasuki dunia siswa "Gaya mengajar guru adalah gaya belajar siswa".

\section{Fungsi dan tujuan Multiple Intellegences}

Tujuan dari adanya teori Multiple Intellegences tidak lain hanyalah untuk mengetahui kecerdasan dari berbagai macam kemampuan siswa, dimana dengan teori ini guru bisa menemukan titik temu tentang kecerdasan perindividu bagi setiap siswa.

Teori ini digunakan dalam pembelajaran antara guru dan murid.Sebenarnya kecerdasan yang dimiliki oleh setiap masing-masing siwa itu dapat dilihat dari prilaku yang diulang-ulang atau bisa dilihat dengan kemampuan yang menonjol dari otaknya.Jika otak kirinnya yang sering berfungsi maka orang tersebut cerdas dalam bidang intelektua dan matemtis.Sedangkan otak kanannya yang sering bekerja maka anak tersebut cerdas dalam bidang seni, bernyanyi, melukis dan lainnya.

Gardner menjelaskan bahwa tujuan dari kecerdasan ada 3;

a). Kemampuan untuk menyelasaikan masalah yang terjadi dalam kehidupan manusia.

b). Kemampuan untuk menghasilkan persoalan-persoalan baru untuk diselesaikan.

c). Kemampuan untuk menciptakan sesuatu atau menawarkan jasa yang akan menimbulkan penghargaan dalam budaya seseorang. ${ }^{12}$

Sedangkan fungsi dari Multiple Intellegences adalahditemukannya strategi guru dalam berkenalan dengan peserta didiknya atau berfungsi untuk menemukan

\footnotetext{
${ }^{10}$ Ibid. 12

${ }^{11}$ Munif Chatib, Sekolah Anak-Anak Juara, Berbasis Kecerdasan Jamak Dan PendidikanBerkeadilan (Bandung: Kaifa Learning, 2012), 78

${ }^{12}$ Linda Campbel, Metode Praktis Pembelajaran Berbasis Multiple Intellegences. (Intuisi Press, 2004). 02
}

Kariman, Volume 06, Nomor 02, Juni 2018| 271 


\section{Lailatul Qadariyah}

karakter yang terjadi pada anak sehingga guru bisa menuangkan pembelajaran sesuai dengan kecerdasan anak asuhnya.

Multiple Intellegences Juga berfungsi untuk meningkatkan kualitas guru dalam mendidik dan mengatur siswa terhadap otak yang lemah. Karena dengan adanya otak yang lemah maka kecerdasa baginya akan mengurang.

\section{Tinjauan Tentang Otak dan Macam-Macam Kecerdasan}

Otak adalah pusat dari intellegensi atau media berfikir untuk mendapatkan ilmu pengetahuan yang kemudian diaplikasikan dalam kehidupan nyata. ${ }^{13}$

Otak juga merupakan organ tubuh yang sangat vital bagi manusia atau pusat kecerdasan dan kemampuan berfikir bagi setiap orang. ${ }^{14}$ yang mana setiap manusia yang lahir kedunia ini dilengkapi dengan otak yang sama. Adapun yang membedakannya dikemudian hari adalah masalah stimulasi. Semakin sering dan intens stimulasi itu dilakukan, maka otak akan mengalami perkembangan yang pesat.

Setiap otak manusi memiliki bermiliar-miliar neuron, bahkan sebelum masa kelahiran otak janin kebanyakan sudah memiliki sel otak yang berjalan aktif disetiap hari. ${ }^{15}$

Disamping itu, otak manusia terdiri dari atas 2 belahan (hemisfer) yaitu belahan otak kiri dan otak kanan, yang mana kedua belahan ini mempunyai fungsi masing.Belahan otak kiri berkaitan dengan fungsi akademik seperti kemampuan berbicara, berbahasa, membaca tulisan, logika, angka dan analisis.Belahan otak kiri juga berhubungan ddengan kecerdasan analitis atau intelek, yang menjadikan manusia memiliki kemampuan matematika dan kemampuan berfikir secara sitematis. Menurut para peneliti bahwa, cara kerja otak kiri rapi dan terstruktur.

Otak besar atau cerebrum adalah bagian terbesar dari otak manusia dan terdiri dari bagian kanan dan kiri yang berperan menjalankan aktivitas sehari-hari manusia. Penelitian membuktikan bahwa otak kiri lebih banyak digunakan untuk proses berpikir secara logika dan dalam berbahasa, sementara bagian kanan lebih berperan untuk proses intuitif dan visual.

Pengakuan otak kiri yang dahsyat ini merupakan bagian otak yang lebih awal diketahui oleh pakar dari pada otak kanan.Otak kiri diketahui mempunyai

\footnotetext{
${ }^{13}$ Abd. Kadir, Misteri Otak Kiri Manusia (Diva Press, Jogjakarta: 2010), 9

${ }^{14}$ Rusdie Salman, Menyiapkan Kecerdasan Matematika Anak Sejak Dalam Kandungan (Jogjakarta: DIVA Press, 2011), 18

${ }^{15}$ Muhammad As'adi, 2010. Panduan Praktis Stimulasi Otak Anak .Jogjakarta: DIVA Press, 41.
} 
fungsi bertanngung jawab dalam bahasa.Oleh karena itu, otak kiri bermamfaat dalam memahami hal-hal yang kompleks dan memerlukan pemikiran khusus. ${ }^{16}$ Diantaranya (mengontrol tubuh bagian kiri, ketrampilan angka-angka, matematika/ketrampilan ilmiah, menganalisa, obyektifitas, menulis, berbicara, logika, pertimbangan)

Ketika manusia lebih dominan menggunakan otak kiri lebih memilih alasan untuk segala sesuatu yang lain. Mereka menggunakan logika rasional untuk mengidentifikasi penyebab masalah, dan kemudian berpikir tentang bagaimana cara mengatasinya. Pada intinya, orang yang berfikir menggunakan otak kiri adalah detail-oriented

Sedangkan operasi dari otak kanan lebih banyak berkaitan dengan sesuatu yang bersifat artistik, kreativitas, perasaan, emosi, gaya bahasa, irama musik, imajinasi, fantasi, warna, pengenalan diri dan orang lain serta pengembangan kepribadian. ${ }^{17}$

Menurut Dewi menjelaskan bahwa otak merupakan organ tubuh yang mengontrol dan mengendalikan semua sistem didalam tubuh. ${ }^{18}$ Sehingga dengan adanya fungsi otak yang bagus dapat menuntukan hidupnya, ini semua tidak terlepas dari kenerja otak yang menjadi motor bagi kenerja manusia.

Orang yang lebih dominan menggunakan otak kanan cenderung menggunakan kreativitas untuk memecahkan suatu masalah.Mereka lebih banyak mengandalkan intuisi dan lebih cepat menangkap gambaran keseluruhan situasi. Pada intinya, orang yang banyak menggunakan otak kanan tidak detail oriented

Namun otak yang berkembang dalam diri manusia berjalan dengan seimbang maka diperlukan. Pertama, Kurikulum : Agar lebih utuh dalam menggunakan otak pada orientasi individu, pendidikan harus memberikan bobot yang sama dengan mengajarkan seni, kreativitas, dan keterampilan imajinasi. Kedua, Instruksi : Untuk menumbuhkan lebih banyak pengalaman skolastik pada kedua sisi otak, pendidik harus menggunakan teknik instruksi yang terkait dengan preferensi kedua sisi otak. Kelas di sekolah bisa meningkatkan kegiatan belajar otak kanan dengan mengikutkan lebih banyak pola, metafora, analogi, bermain peran, visual dan gerakan membaca, perhitungan, dan kegiatan analitis.Ketiga,

\footnotetext{
${ }^{16}$ Abd. Kadir, Misteri Otak Kiri Manusia. (Diva Press, Jogjakarta: 2010), 88.

${ }^{17}$ Rusdie Salman. 2012. Menyiapkan Kecerdasan Matematika Anak Sejak Dalam Kandungan. DIVA Press.Jogjakarta, 47.Buku ini mengalami persamaan dengan bukunya Abd. Kadir tentang fungsi otak kanan, akan tetapi Abd. Kadir menambah didalam bukunya bahwa para ahli banyak yang mengatakan otak kanan memegang peranan penting bagi perkembangan $E Q$ (Emotional Quotiont) seseorang.

${ }^{18}$ Ibid. Hal, 18.
}

Kariman, Volume 06, Nomor 02, Juni 2018| 273 


\section{Lailatul Qadariyah}

Penilaian : Untuk evaluasi yang lebih akurat, pendidik harus mengembangkan bentuk-bentuk penilaian baru yang mengembangkan bakat dan keterampilan dengan menggunakan rotak kanan

1. Macam-macam kecerdasan

Macam-macam kecerdasan ada 9 yaitu :

1) Kecerdasan linguistik (cerdas bahasa)

Kecerdasan linguistik merupakan kemampuan berfikir dalam bentuk kata-kata, menggunakan bahasa untuk mengekspresikan, dan menghargai makna yang komplek. Hal ini mempunyai karakter yaitu, mendengar serta merespon setiap suara, warna dan berbagai ungkapan kata dan menyimak secara efektif, memahami, menguraikan, menafsirkan dan mengingat apa yang telah di ucapkan.

Kecerdasan ini, memilik kondisi akhir terbaik yaitu menjadi cerpenis dan satrawan, pembaca puisi dan penulis buku.Sedangkan tokohnya seperti Andrea Hirata (Novelis) dan Salman Aristo (Penulis Skenario). ${ }^{19}$

2) Kecerdasan logis-matematis (Cerdas Angka)

Kecerdasan logis-matematis adalah kemampuan menghitung dalam mengukur dan mempertimbangkan proposisi serta menyelesaikan angka-angka.Karakteristik ini mempunyai kepekaan dalam memahami pola-pola logis atau numeris dan kemampuan mengolah alur pemikiran yang panjang; dan mengenal konsep-konsep yang yang bersifat kuantitas, waktu, hubungan sebab akibat.

Kondisi akhir terbaik dari kecerdasan ini menjadi astronot, ahli ekonomi, ahli statistik dan bankir.Sedangkan tokohnya seperti BJ.Habibie (pakar tekhnologi pesawat) dan Andi Hakim Nasution (dosen ahli statistik). ${ }^{20}$

Kecerdasan ini hanya mengarah kepada simbol atau angka.Yang mana kumpulan dari pada angka dan simbol pada bilangan disebut dengan matematika.Para ilmuwan menyandingkan antara matematika dan logika, karena dasar dari logika dibangun melalui argumen, validitas, bukti, difinisi dan konsistensi. Dengan ini bahwa logika membutuhkan kevalidan yang sama dengan matematika.

\footnotetext{
${ }^{19}$ Seto Mulyadi. 2012. Sekolah Anak-Anak Juara Berbasis Kecerdasan Jamak Dan Pendidikan Berkeadilan.Mizan Media Utama. Bandung. 82

${ }^{20} \mathrm{Ibid} .86$
} 
Kecerdasan ini melibatkan banyak komponen : perhitungan secara matematis, berfikir logis, nalar, pemecahan masalah, pertimbangan deduktif dan ketajaman hubungan antara pola-pola numerik. ${ }^{21}$

3) Kecerdasan spasial-visual (cerdas ruang dan gambar)

Kecerdasan spasial-visual adalah cara pandang dalam proyeksi tertentu dan kapasitas untuk berfikir dalam 3 cara dimensi. Kecerdasa disini memungkinkan seseorang untuk melakukan eksplorasi imajinasi, misalnya memodifikasi bayangan suatu objek dengan melakukan percobaan sederhana.

Karakteristik dari kecerdasan ini yaitu belajar dengan melihat dan mengamati.Mengenali wajah-wajah, benda-benda, bentuk-bentuk, warnawarna, detail- detail dan pemandangan.

Sedangkan akhir kecerdasan kondisi ini, menjadi seniman, perancang, pelukis, pengamat seni dan pembuat patung.Sedangkan tokohnya seperti Joko F. Purwoko (Instruktur penerbangan pesawat tempur) dan Marsekel Pnb. Basri Sidehabi (Pilot F-16). ${ }^{22}$

4) Kecerdasan kinestesis (cerdas olah tubuh -jasmani)

Kecerdasan kinestesis adalah kemampuan belajar lewat tindakan dan pengalaman melalui praktek langsung.Jenis kecerdasan ini lebih senang berada dilingkungan tempat dia bisa memahami sesuatu lewat pengalaman nyata.Kemampuan bergerak disekitar objek dan keterampilanketerampilan fisik yang halus dan kemampuan mengolah tubuh kedalam bentuk gerakan tertentu merupakan pola dasar kecerdasan kinestesis.

Karakter kecerdasan konestesis menjelajahi lingkungan dan sasaran melalui sentuhan dan gerakan, mempersiapkan untuk menyentuh, menangani atau memainkan apa yang akan menjadi bahan untuk dipelajari dan menunjukkan keterampilan dalam arti menggerakkan kelompok besar atau kecil.

Out come dari kecerdasan konestesis menjadi atlet, penari, guru tari, karateka dan aktor. Sedankan tokohnya seperti Deni malik (Penata Tari) dan Dr. Syamsul Burhan (Spesialis Bedah).23

\footnotetext{
${ }^{21}$ Ibid. 73

${ }^{22}$ Ibid. 88

${ }^{23}$ Ibid. 90
} 
Lailatul Qadariyah

5) Kecerdasan musik

Kecerdasan musik merupaka kemampuan seseorang yang punya sensitivitas pada pola titi nada, melodi, ritme dan nada. Musik tidak hanya dipelajari secara auditori tapi juga melibatkan semua fungsi panca indra.

Karakter kecerdasannya mendengarkan dan merespon dengan ketertarikan terhadap berbagi bunyi, termasuk suara manusia, suara-suara dari lingkungan alam sekitar dan musik, serta mengorganisasi berbagai jenis suara mkedalam pola yang bermakan.

Kondisinya yang terbaik dari kecerdasan musik menjadi penyanyi, kompose, musisi, pencipta lagu dan pemain musik.Sedangkan tokohnya seperti Gilang Ramadlan (Musikus) dan Doel Sumbang (pencipta lagu) ${ }^{24}$

6) Kecerdasan interpersonal (cerdas bergaul)

Kecerdasan interpersonal adalah kemampuan memahami dan berinteraksi dengan orang lain secara efektif. Kecerdasan interpersonal memungkinkan kita bisa memahami dan berkomonikasi dengan orang lain. Termasuk juga kemampua membentuk juga menjaga hubungan serta mengetahui berbagai peran yang terdapat dalam suatu kelompok.

Karakter Kecerdasan interpersonal yaitu terikat dengan orang tua dan berinterksi dengan orang lain. Mengetahui dan membentuk hubungan sosial.

Out come dari kecerdasan ini menjadikonselor, politikus, negosiator dan penghibur. Sedangkan tokohnya seperti Akbar Tnajung (Politikus) dan Jusuf Kalla (Negosiator). ${ }^{25}$

Kecerdasan ini bisa desebut kemampuan memahami dan berinteraksi atau berhubungan dengan orang lain secara efektif. Hal ini terlihat pada guru pekerja sosial, artis atau politisi yang sukses, ini semua dikarenakan adanya hubungan yang kuat dengan orang lain. ${ }^{26}$

7) Kecerdasan intrapersonal (cerdas diri)

Kecerdasan intrapersonal adalah kemampuan membuat presepsi yang akurat tentang diri sendiri dan menggunakan pengetahuan semacam

\footnotetext{
${ }^{24}$ Ibid. 92

${ }^{25}$ Ibid. 94

${ }^{26}$ Muhammad As'adi . 2010. Panduan Praktis Stimulasi Otak Anak. DIVA Press. Jogjakarta. 36
} 
itu dalam merencanakan dan mengarahkan kehidupan seseorang.Anak belajar melalui perasaan, nilai-nilai dan sikap.

Karakteristik kecerdasan intrapersonal adalah memahami perasaan sendiri, pengetahuan tentang pengenalan diri sendiri termasuk kekuatan dan kelemahan diri.Juga menemukan cara-cara atau jalan keluar untuk mengekspresikan perasaan dan pemikirannya.

Sedangkan kondisi terbaiknya dalam kecerdasan ini, menjadi psiko-terapis, pemimpin agama, penasehat dan filsuf.Tokohnya meliputi Mario Teguh, Ari Ginanjar dan Agustian (Mutivator). ${ }^{27}$

8) Kecerdasan naturalis (Alam)

Kecerdasan naturalis adalah jenis kecerdasan yang erat berhubungan dengan lingkungan, flora dan fauna, yang tidak hanya menyenangi alam untuk dinikmsti keindahannya.Akan tetapi sekaligus juga punya kepedulian untuk kelestarian alam tersebut.

Karakteristi Kecerdasan naturalis adalah merupakan kesadaran untuk menjaga kelestarian lingkungan dari kerusakan lingkungan dan ketidak seimbngan ekosistem.Juga dapat meneliti gejala-gejala alam, mengklasifikasikan dan mengidentisifikasi penyebab gejala-gejala alam.

Out come kecerdasan ini menjadi peneliti, ahali cuaca, Ahili Gunung berapi, dokter hewan dan ahli geologi. Tokohnya seperti Edwin Norman, Uli sigar rusyadi (Anggota LSM Lingkungan/pencinta alam) ${ }^{28}$

9) Kecerdasan eksistensialis (cerdas spritual)

Kecerdasan eksistensialis adalah kesiapan manusia dalam menghadapi kematian. Sedangkan karakternya adanya kesadaran akan Tuhan atau memiliki ciri-ciri cendrung mempertanyakan sikap sesuatu mengenai keberadaan manusia, arti kehidupan, mengapa manusia mengalami kematian dan realitas yang dihadapinya.

Kondisi akhir terbaiknya tidak dapat dinyatakan dalam dunia kerja atau sebagai profesi, tetapi meruapakan wujud kesiapan dan bekal manusia menuju kehidupan yang kekal setelah kematiam.Tokohnya seperti para nabi, rosul dan shahabat. ${ }^{29}$ Kemampuan kecerdasan yang

\footnotetext{
${ }^{27}$ Seto Mulyadi. 2012. Sekolah Anak-Anak Juara Berbasis Kecerdasan Jamak Dan Pendidikan Berkeadilan.Mizan Media Utama. Bandung. 97

${ }^{28}$ Ibid. 99

${ }^{29}$ Seto Mulyadi. 2012. Sekolah Anak-Anak Juara Berbasis Kecerdasan Jamak Dan Pendidikan Berkeadilan.Mizan Media Utama. Bandung. 78 . Buku ini mengalami perbedaan tentang Multiple Intellegences dengan bukunya Sri
} 


\section{Lailatul Qadariyah}

dimiliki seorang anak pada suatu saat ditentukan oleh 3 faktor yang saling bekerjasama, antara lain :

a). keadaan otak anak beserta susunan syarafnya yang merupakan turunan dari orang tuanya.

b). Perubahan-perubahan, kerusakan pada susunan syaraf yang diakibatkan oleh cedera atau penyakit, sebelum maupun sesudah anak lahir

c). Lingkungan dan pengalaman anak itu sendiri. ${ }^{30}$

\section{Kesimpulan}

1. Konsep pembelajaran berbasis Multiple Intelligences dalam perspektif Munif Chatib merupakan koreksi terhadap kecerdasan seseorang tidak hanya berdasarkan pada Intelligences Quotient (IQ) yang hanya mengukur kemampuan seseorang hanya berdasarkan pada linguistik, matematik logis dan spasial saja. Juga Munif Chatib memaparkan bahwa konsep penerapan pembelajaran atau pendidikan berbasis Multiple Intelligences secara global meliputi tiga tahap penting, yaitu; input, proses dan output. Pada tahap input, menggunakan Multiple Intelligences Research dalam penerimaan peserta didik barunya. Tahapan yang kedua adalah tahapan pada proses pembelajaran, dimana nantinya gaya mengajar gurunya harus sama dengan gaya belajar pesertadidikya. Pada Output, dalam pembelajaran berbasis Multiple Intelligences ini, maka penilaiannya yaitu dengan menggunakan penilaian Autentik.Penilaian autentik adalah sebuah penilaian terhadap sosok utuh seorang peserta didik yang bukan diukur dari segi kognitifnya saja melainkan juga diukur dari segi afektif dan psikomotorik peserta didik. Dalam konsep pendidikan Multiple Intellegences Munif Chatib lebih menekankan pada The Best Proses bukan The Best Input dimana sekolah unggul adalah sekolah yang fokus pada kualitas proses pembelajaran, bukan pada kualitas input siswanya.

2. Menurut Munif Chatib Didalam buku "Gurunya Manusia" mengatakan bahwa strategi yang baik untuk menciptakan anak istemewa atau bahagia lewat Multiple Intellegences adalah ditekankan pada kreativitas guru dan keahlian

Narnwanti, ia mengatakan bahwa Multiple Intellegences ada 8. Yaitu semua kecerdasan kecuali kecerdasan eksistensialis (cerdas spritual)

${ }^{30}$ Sunartyo Nano. 2006. Membentuk Kecerdasan Anak Usia Dini. Think, Jogjakarta. 124

278 | Kariman, Volume 06, Nomor 01, Juni 2018 
dalam mengaplikasikannya, hal ini dapat kita lakukan dalam dunia pembelajaran antara guru dan murid. Munif Chatib mengartikan strategi mengajar dengan menekankan kepada kekreativitas guru sehingga jumlah dan nama strategi itu harus luas dan tak terbatas. Jadi, apapun namanya, strtegi Multiple Intelligencesakan menjadi wadah yang sangat luas dan dapat menampung semua istilah metodologi pembelajaran. Pendapat Munif Chatib disetujui oleh beberapa pakar pendidikan bahwa strategi Multiple Intelligences sangat bermamfaat untuk pemilihan strategi mengajar oleh guru. Seperti strategi diskusi (keampuhannya adanya komonikasi dan intraksi diantara dua orang atau lebih), action research (aktivitas pembelajarannya yang meminta siswa untuk membuat hepotetis), klasifikasi (belajar dengan cara pengelompokan) dan analogi (pemahaman konsep dengan cara membuat persamaan suatu bentuk dengan bentuk lainnya).

\section{DAFTAR PUSTAKA}

Al-Fandi, Haryanto, Desain Pembelajaran Yang Demokratis Dan Humanis, Jogyakarta: Ar-Ruzz Media, 2011.

As'adi, Muhammad, Panduan Praktis Stimulasi Otak Anak, Jogjakarta: DIVA Press. 2010.

Campbell, Linda dkk, Metode Praktis Pembelajaran Berbasis Multiple Intelligences, Intuisi Pers, 2004,

Chatib, Munif, Gurunya Manusia menjadikan Semua Anak Istimewa dan Semua Anak Juara. Bandung: Mizan Media Utama, 2011.

Sekolah Anak-Anak Juara, Berbasis Kecerdasan Jamak Dan Pendidikan Berkeadilan, Bandung: Kaifa Learning, 2012.

Sekolahnya Manusia, Sekolah Berbasis Multiple Intelligences Di Indonesia, Bandung: Kaifa Learning, 2011.

Hasan, M. Afif, Ilmu Pendidikan Islam. Malang: IKIP MALANG, 2011.

Hasan. Maimunah, pendidikan Anak usi Dini. Jogjakarta: DIVA Press. 2012.

Kadir, Abd. Misteri Otak Kiri Manusia, Diva Press, Jogjakarta: 2010. 
Lailatul Qadariyah

Kadir, Abd. Misteri Otak Kiri Manusia. Diva Press, Jogjakarta: 2010.

Khazim, Muhammad Nabil, Sukses Mendidik Anak Tanpa Kekerasan, Sebuah Konsep Pendidikan Anak Yang Ideal Dan Seimbang, Nasional RI, solo; 2011.

Muhammad, Yaumi, Pembelajaran berbasi Multiple Intellegences, Jakarta: Dian rakyat, 2012.

Musthafa, Aziz, Aku Anak Hebat Bukan Anak Nakal. Jogjakarta: DIVA Press. 2009.

Nizar, Imam Ahmad Ibnu, Membentuk dan meningkatkan Disiplin Anak Sejak Dini. DIVA Press, Jogjakarta; 2009.

Salman, Rusdie, Menyiapkan Kecerdasan Matematika Anak Sejak Dalam Kandungan, Jogjakarta: DIVA Press, 2011.

Salman. Rusdie, Menyiapkan Kecerdasan Matematika Anak Sejak Dalam Kandungan. Jogjakarta: DIVA Press, 2012.

Slameto, Belajar Dan Faktor-Faktor Yang Mempengaruhinya, Jakarta: PT. RINEKA CIPTA, 2003.

Sunartyo, Nano, Membentuk Kecerdasan Anak Sejak Dini, Jogyakarta: Think, 2006.

Yaumi, Muhammad, Pembelajaran Berbasis Multiple Intellegences, Jakarta: Dian rakyat, 2012. 